\title{
COST-VOLUME-PROFIT ANALYSIS OF POWER SECTOR INDUSTRY IN BANGLADESH: A STUDY ON BARAKA POWER LIMITED
}

\author{
Tahrima Chowdhury Jannath \\ Lecturer of Accounting and Information Systems, Department of Business Administration, \\ Leading University, Sylhet, Bangladesh
}

\begin{abstract}
Cost Volume Profit (CVP) analysis is considered as the most powerful device to increase the chances of making profits in today's competitive business market. Such analysis helps a company to make decisions such as enhancement of sales, and making revenues. CVP analysis depicts the relationship among different components, specifically, variable cost, sales volume and product cost which can help in planning how to make revenues. Cost Volume Profit analysis plays a vital role in the managerial decision making processes. The organization can decide the type of products that needs to be created for reaching the desired outputs, the number of units that needs to be distributed, attaining obligatory benefits under numerous cost and volume affiliation. The objectives are to find out the Cost Volume Profit (CVP) of Baraka Power Limited of the periods (2016-2020) and to calculate the company's Break-Even point. To satisfy the objectives, five year financial information has been considered from the period 2016-2020 in the form of secondary data. The data have been collected from the Annual Reports of the company and the company's website. The data were then analyzed and recommendations were also given. The results showed a steady increase throughout the studied periods in their sales and contribution level. Based on the fluctuating profit-volume ratio and break even sales results, it was recommended that the company should consider lowering their fixed costs and increasing their sales in their upcoming future. It was also recommended that the company can use CVP analysis to make appropriate decisions for making profits.
\end{abstract}

Key Words: Cost Volume Profit, Power Sector Industry, Baraka Power, Bangladesh.

\section{INTRODUCTION}

In order to survive in today's competitive business market; a business organization needs to be competent in performing their activities. A company's performance can be measured by analyzing its productivity levels. Productivity can be measured by considering the company's output maximization, cost minimization, or profit maximization. In order to match up with other firms in worldwide market, companies such as industrial companies, banks, private companies no matter if it is large or small, organizations must reach to their optimum presentation. Hence, improvising performance has been one of the major concerns of today's businesses. CVP (Cost-Volume-Profit) analysis plays a pivotal role in assessing the performance and valuing the managerial performance in different sections of an organization mostly in industrial organizations. Such analysis are used by the management of an organization for identifying the level of operating activities which should be considered to avoid losses, reach the desired profits, make future operation plans, and observe the organizational performance. The concept of cost volume profit analysis is based on the fact that changes in prices and volume of a company's products can have an effect on a company's profit. The key reason which influences the acquiring of profit is the degree of production. Enhancing the profit is the ultimate objective of any organization. In order to earn revenues and maximize it, the organization should plan and select an appropriate strategy.

The CVP analysis discusses the quantitative analysis method which studies the cost behavior analysis, and uses mathematical model of accounting to disclose the internal laws of fixed costs, variable costs, sales price, sales volume, profits and other associated variables. The results from this analysis can provide required financial information for accounting forecast, decision-making and planning. With this tactic, enterprises can forecast the only amount of sales of their products that needs to break-even, or estimate how much profit can be made from a certain amount of sales, or predict the amount of products that must be produced for making a definite revenue, or the number of price of the products that must be reduced for increasing the sales volume which can in turn help to state the current position of the manufacturing company and help make a decision of how well the manufacturing company is performing its operation and how far the company has been able to use its resources and earn income.

The contribution margin resulting from short run choices, target costing and transfer pricing can be studied by analyzing cost volume and profit benefit analysis. On a large scale the term cost volume and profit is a method that identifies 


\section{DOI: 10.17148/IARJSET.2021.81108}

revenue, costs and sales at different levels of activity. And on a small scale, this term implies on calculating the breakeven point. Break-Even point is considered a point where total costs equal to total sales. In this point the company incurs no profit and no loss. It is important for any businesses to analyze exactly how they need to sell in order to break-even. The term break-even means covering all costs without making a profit.

Bangladesh, a country with more than 160 million populations is considered as the world's most populated countries. Speedy development in the living standards of the people residing in this country has generated a requirement of large need of electricity. It cannot be denied that energy plays a vital role in the extinction of poverty, growth of economy, infrastructure development of a country and maintaining safety of a country.

The most commonly used energy in Bangladesh is electricity. Hence, the upcoming development of an economy depends on the accessibility of power. The government of Bangladesh should make sure that the electrical energy is available to its country's people in a reasonable and ecologically friendly way. This sector of the country was hardly successful in inviting satisfactory private investments in electricity business because of poor pricing policies. This scarcity of investment is a major reason behind power calamity.

The objective of this study is to investigate the performance of power plant industry specifically Baraka Power Limited in Bangladesh using CVP analysis and further study its Break-Even Point. In the next section of the study there are earlier literature studies based on the concept of CVP analysis and its role on the decision taken by the management of various organizations which is later followed by the data analysis and interpretation of the calculations of contribution margin and Break-Even Point of Baraka Power Limited, Bangladesh. Finally, the results are concluded by suggesting ways for further study.

\section{BACKGROUND OF POWER SECTOR INDUSTRY IN BANGLADESH}

According to the report titled, "Energy Sector in Bangladesh", in "An agenda for reforms" on March 2014, bringing electricity in the capital city of Bangladesh began in Dhaka in 1901, which is right 19 years after New York and 13 years after London. It was brought by then Nawab Khwaja Ahsanullah.

Saiful Islam, Md. Ziaur Rahman Khan, (2017) found that later a Board of Directors team for the electricity sector was established in East Pakistan in the year 1948. A couple of Steam Turbines with highest size of 10 MW were established in Siddhirganj Chittagong and Khulna area at that time.

M.Zakir Hossian Khan and M. Rasheduzzman, in their study titled "Performance of the Power Sector of Bangladesh: Governance Failures and Remedial Measures", at, Transparency International Bangladesh (TIB) found that, in the year 1962, a 40 MW Kaptai hydro-electric project was mounted with a $132 \mathrm{kV}$ communication line between Dhaka and Chittagong was custom made. Right after the Independence of Bangladesh which is on the year 1971, only 3\% of the country's total population had access to electricity.

As per the reports from Sustainable Energy for All (SE4ALL) database from World Bank, shows that $79 \%$ of the country's population earlier had suffered from load-shedding problems, and $60 \%$ of the consumers encountered low voltage supply.

In a report named, "Govt plans to sign energy pact with Bangladesh", at The Himalayan Times (2018), it has been found that after the year $2015,92 \%$ of the metropolitan population and $67 \%$ of the country side population had access to electricity. A mediocre of 77.9\% of the population had access to electricity in Bangladesh after the year 2017.

As per the reports of Bangladesh Power Development Board in the year July 2018, 90 percent of the country's population had access to electricity.

Source of Light in Bangladesh, (2015), stated, Bangladesh will require a projected 34,000 MW of power by 2030 to withstand its economic growth of over 7 percent.

\section{CURRENT SCENARIO}

As per the reports of "Nuclear Power in Bangladesh", (2017), the utility electricity sector in Bangladesh has one national grid with an installed capacity of 21,419 MW since September 2019. The energy sector of Bangladesh is uprising. And currently the connected capacity is 20,000 MW (combining solar power). In recent times, Bangladesh has started building up a 2.4-gigawatt (GW) Rooppur Nuclear Power Plant that will hopefully start its action in the year 2023.

"Key Statistics", Bangladesh Power Development Board (2018), showed electricity is required to efficiently run a number of economic activities in Bangladesh. As of January 2017, Bangladesh's total installed electricity generation capacity (including captive power) was 15,351 megawatts (MW) and 20,000 megawatts in the year 2018

Dr Khondaker Golam Moazzem, Mohammad Ali, (2019) identified that out of many successful cases of the present government in Bangladesh, power and energy sector is the most promising projects. This was possible by taking up the challenges of achieving the directed. The study showed that the power and energy sector is one of the success cases of the present government during initiatives from the last 10 years with a hope to bring the country out of electricity. The 


\section{DOI: $10.17148 /$ IARJSET.2021.81108}

country's power and energy sector is moving towards reaching its long term goals which is 27,400 MW (in 2030), and 51,000 MW (in 2041) for safeguarding the sustainability of energy.

\section{POWER AND ENERGY SECTOR VALUE CHAIN}

Dr Khondaker Golam Moazzem, Mohammad Ali, (2019) showed that the value chains in the power and energy sectors are obviously directed by that of the power sector. This is mainly because of the calamity in the power sector specifically before the year 2010 which produced over-demand of electricity. The following figure depicts the connections of different value chains related to the power and energy sector. The achievement of this sector is largely focused by the power sector. Accordingly, the basic energy sector that includes gas LNG), coal, petroleum and renewable did not receive adequate consideration.

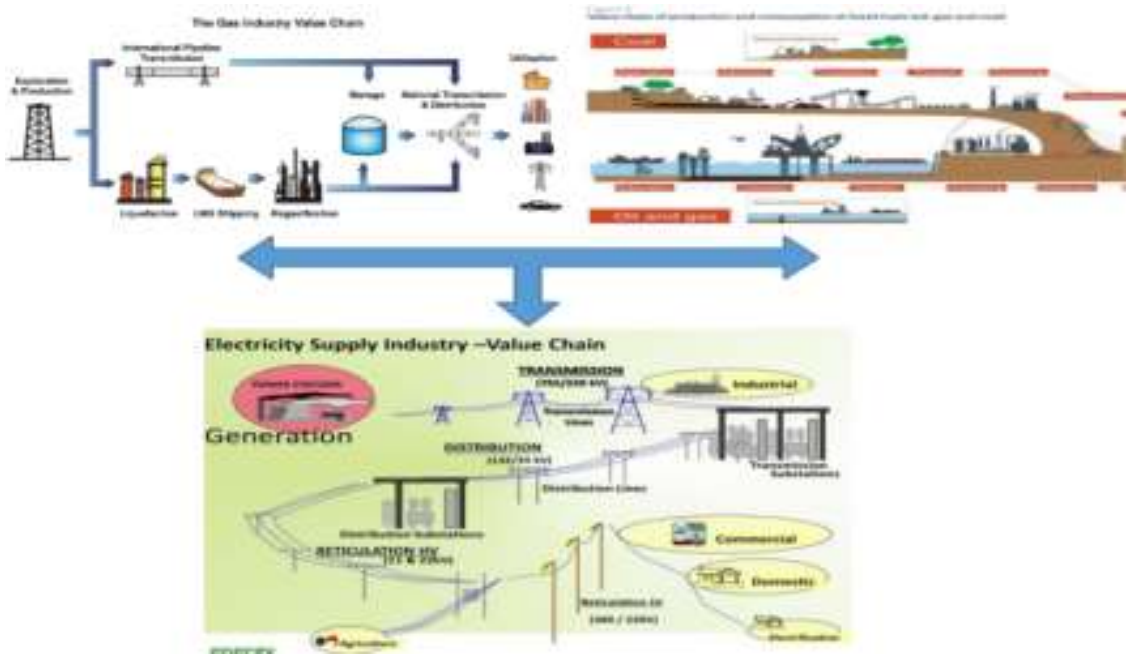

Source: Assembled from different websites

Figure 1: Interlinkages of Power and Energy Sector Value Chain

\section{ABOUT BARAKA POWER LIMITED, BANGLADESH}

Baraka Power Limited emerged at the time when Bangladesh was going through huge catastrophe of power. The country desperately required adequate amount of power to meet up the needs of socio economic sector power. It was only then when Baraka Power was initiated as joint teamwork of a group of Non Resident Bangladeshis (NRBs) foreign earnings and some local business persons. Baraka Power is a private sector power producing company which started in Bangladesh on 26 June 2007 as a Private Limited Company. The company transformed into Public Limited Company on 25 September 2008 under the companies Act, 1994. The company changed its original name from "Barakatullah Electro Dynamics Limited" to its current name "Baraka Power Limited" on January 12, 2015

The company got its name enlisted at both Dhaka Stock Exchange Limited and Chittagong Stock Exchange Limited on 16 May 2011 and started trading of its shares from 19 May 2011.

(Annual-Report-2019-2020-of-Baraka-Power-Ltd.-1.pdf), Baraka Power Limited was bestowed 50 MW IPP HFO based power plant at Patenga under the open tendering method in the year 2011. Consequently, Baraka Power Limited made a subsidiary company namely Baraka Patenga Power Limited (BPPL) to plan, fund, secure, build, possess, commission, function and maintain a $50 \mathrm{MW}$, HFO-fired power generating facility at South Patenga, Chattogram for a period of 15 years. The BPPL plant started its official operation from May 04, 2014 and since then the company is uninterruptedly providing electricity to the National Grid successively.

\section{A. FORM of BUSINESS}

(Annual-Report-2019-2020-of-Baraka-Power-Ltd.-1.pdf), The main purpose of Baraka Power Limited is to develop set up power plants for the production and delivery of electricity. Conversely, the company is also considering at achieving contracts for the application of new projects at Engineering, Procurement and Construction (EPC) sector. Alongside, the company also financed in three other power plants, one garments project and one school project.

\section{B. MAIN PRODUCTS and SERVICE}

(Annual-Report-2019-2020-of-Baraka-Power-Ltd.-1.pdf), Electricity is the main invention of the company. Under the policy of private sector power generation in Bangladesh, Baraka Power Limited has been delivering electricity successively to the Bangladesh Power Development Board (BPDB) through the national grid. 


\section{FUNDAMENTAL ELEMENTS OF CVP ANALYSIS}

K. Malarkodi ,M. Ranjitha(2021), stated Cost, Volume and Profit are the most important components of CVP analysis. These three elements help to decide the prospects of a business in a long run.

- Cost: cost is the basic requirement to run a business. Cost indicates the amount of money that an organization applies on the formation or creation of goods and services. Every business incurs expense at its initial stage and carries on as it does its business.

- Volume; Volume is the second important constituent of the business. It depicts shows how much an organization will produce and sell.

- $\quad$ Profit: The last and most major element is the profit of a business. While conducting a business one should stay updated about how much profit it has made by conducting the activities such as delivery of product and services to its customers.

\section{SOME PERTINENT LITERATURE}

Cost volume profit analysis is one of the main management tools that are used for analytical purposes. To prove this saying a study has been done by Halil Akmese, Ahmet Buyuksalvarci, Kadriye Akmese (2016). Data has been collected by using a survey questionnaire. Results of the study showed that CVP analysis can add value to the business when using with other different techniques rather than using alone.

It was after Second World War, study of cost accounting was improvised to management accounting as stated by Shah Haider et. al. (2011). As per the researcher, use of management accounting is helpful for making decisions. New potentials are being made as the outmoded management accounting did not properly utilize the strategic thinking and other qualitative features of management, thus making accounting more significant and vital for managers.

Cost volume profit analysis is described as an estimation of how the company's profit is affected with the changes in costs such as vriable and fixed costs, sales volume and prices as said by Abdullahi (2015).

A study has been conducted by Dr. R. Kavitha (2018) on cost volume profit analysis in order to see the company's profitability that is based on the production of cost and volume. A proper study of the cost volume and profit can express how much expenditure is to be done in order to create the adequate amount of goods that can help the company reach its profit goals. The scholar used techniques such as ratio analysis and break even analysis in order to identify the profitable position of the firm. Finally, the scholar concluded by saying that management can use cost volume productivity analysis to calculate the return of profits by a certain amount of selling goods.

To identify right how much cost volume profit analysis is needed to conduct the planning process, A research was done by Enkeleda Lulaj, Etem Iseni (2018) to recognize exactly how much cost volume profit analysis is required for planning and constructing a business atmosphere. The area of study was manufacturing and service enterprises and with consumers. Mann-whitney U test, burner munzel test, degree of freedom, bootstrap including dependent and independent variables were the statistical tools that were used to conduct the study. Prior to the study the researcher assumed that the techniques in CVP analysis should be used at a wider scale in all organizations. The inspection found that CVP analysis is supposed of and undertakes an important part in vigorous cycle in the manufacturing environment which in turn influences changes made by the organization for the products to be distributed.

However, Adeniyi (2008), believes that cost-volume profit analysis are preset costs, target costs or pre planned costs which management encounters to accomplish the optimum effectiveness in the manufacturing process. As per the researcher, the planning of cost is related to a single cost unit. The preset costs are known as cost-volume-profit analysis and the change between the cost-volume-profit analysis and actual costs are known as a variance. While, Colin, D. (2008) stated that Cost-volume-profit analysis is a target cost which should be reached.

Drury (2000) further carried on the study about cost-volume-profit analysis as preset cost stating that such costs should be blemished under well-organized working conditions. As per the scholar, cost-volume profit analysis may be may be determined on a number of bases. Cost-volume-profit analysis is mainly used in performance measurement, control, stock valuation and in the establishment of selling prices.

Another study by has been done by Kenneth Enooch Okpala, ChimsunumOsanebi (2020) on cost volume profit analysis and profit planning. The study examines using cost volume profit method on giving benefits in manufacturing SMEs as a means to handle the problem. The study collected its information by conducting surveys. For doing its data analysis, descriptive analysis, pearson correlation and regression analysis methods were used. The results of the study stated that profit planning is basically affected by the methodologies of cost volume and profit analysis. The study recommended that the management on manufacturing SMEs should use and grip bookkeepers as well as reconstruct their managerial team for efficacy.

Stefan (2012), believes that CVP analysis acts as linkage that fills out the limitations between accounting and budgetary control and financial economics models for calculating the flexibility in economic decisions. 


\section{DOI: 10.17148/IARJSET.2021.81108}

Sadiq Rabiu Abdullahi, Bello Abiodun Sulaimon, Ibrahim Salihu Mukhtar, Muhammed Hardy Musa (2017), for finding out if small scale businesses use CVP analysis as a management tool for decision making process, has conducted a survey research. The scholars used Mann-Whitney U test and Pearson correlation coefficient tools in their study. The study also analyzed the usage of the term break-even analysis instead of CVP analysis. The scholars believe that the former term is only concerned with the level of activity which shows no profit no loss. This point is known as break-even point. The scholars have shown a nearby relationship between the cost, volume and profit. If volume rises, the cost per unit will fall down, and profit per unit will increase. Hence, there is a straight relation between volume and profit but opposite relation between volume and cost. Such studies are now becoming an important issue for the cost and management accountant to explore. The study summarizes that cost volume profit investigation and other administration accounting tools should be accustomed with private company industry in order to increase their effectiveness.

A different mode of study has been done by Dr. Seung Hwan Kim (2015) where cost volume profit analysis has been done for a multi-product company. This study characterizes how the created method finds the closest solutions to come back to the initial investment point. The researcher identified that the micro approach way is the best way for finding nearby solutions to the break-even point and conducting cost volume profit analysis for a multi-product organization. Additionally, Lucey (1996) narrated breakeven analysis as "the term given to the study of the inter-relationships between costs, volume and profit at various levels of activity"

In order to understand the relation between level of sales and cost volume profit, a study was conducted by $\mathrm{R}$. Punniyamoorthy (2017). The scholar wanted to see this issue as a criterion to achieve a desired profit. The work backs up with differentiating the association's expansion and prospect. The study used secondary data for its analysis. Breakeven point, PV ratio, margin of safety and contribution are the financial tools that were used to conduct the study. The study concludes by stating that cost volume profit analysis is employed as a device that is used in the process of planning which the organization's use to analyze the company's future volume of development, costs and expected profits.

Horngen et al (2006) gave the following assumptions of cost-volume profit analysis

- The performance and incomes is direct.

- Selling price is persistent.

- Costs can be classified into fixed and variable cost.

- Total fixed cost remains the same.

- Total variable cost is proportional to volume.

- Volume is the only factor that drives the cost.

- Prices of production inputs (such as materials) are continuous.

CVP analysis is further followed by identifying the break-even point of the particular analysis. B. Naveneetha, K. Punitha, Raichu Mercy Joseph, S. Rashmi, T Sai Aishwariya (2017) has performed a study on CVP analysis in order to find out the influence of contribution and profit volume proportion of the firm as well as to investigate the break-even point of the firm. The devices used for the study are ration and break-even analysis. In the study cost volume profit shows the linkages between changes in action and changes in sales income, cost and advantages. The study also depicted the volume of a product that should be sold so that the business can reach its starting investment level. The investigator concludes by saying that the analysis of cost volume profit should look at the changes in the output level, selling value, variable cost per unit and fixed expense of a product or management.

Simshauser \& Ariyaratnam, (2014) investigated a different mode of study that showed what level of profit is usual for power generation. In the same mood, Magee (1975) lectured that the CVP analysis is a rough device for sensitivity study in managerial decision-making when it comes to giving importance of the effects on profit at different levels of activity and different combinations of fixed and variable costs of production.

Simultaneously to the progresses in other developed and developing countries observation about application of cost and management accounting practices are gaining the thrust in Bangladesh as said by Farjana Yeshmin (2015). However, (Shil, Nikhil Chandra1; Alam, Mohammad Faridul; Naznin, Mahmuda, 2010) gave a contrasting view that the studies on Cost Management Accounting Practice (CMAP) is very uncommon in Bangladesh, which is why researchers these days are very keen at conducting studies in this area. It will expand the possibility of further studies hence promoting the experts to come up with possible answers to the problems recognized in the study.

\section{OBJECTIVE OF THE STUDY}

- $\quad$ To find out the Cost, Volume and Profitability of Baraka Power Limited of the periods 2016-2020.

- $\quad$ To find out the Break-Even point of the company from the periods 2016-2020.

\section{RESEARCH METHODOLOGY}

The research is conducted from secondary data. Secondary data is collected from

- $\quad$ Annual reports of Baraka Power Limited of the periods 2016-2020. 
International Advanced Research Journal in Science, Engineering and Technology

Vol. 8, Issue 11, November 2021

DOI: 10.17148/IARJSET.2021.81108

- Company's website

- Journals

\section{TOOLS USED FOR DATA ANALYSIS}

CVP analysis and Break-Even analysis.

\section{DATA ANALYSIS AND INTERPRETATION:}

\section{A. DATA ANALYSIS}

Contribution Margin: This is the amount that is remaining from sales revenue after deducting variable expenses. This is the amount that is available to cover fixed expenses and then provide profits for the period.

Contribution $=$ Sales - Variable cost

Table 1: Contributions

\begin{tabular}{|l|l|l|l|}
\hline \multicolumn{1}{|c|}{ Year } & Sales (Tk) & Variable Cost (Tk) & Contribution \\
\hline $2016-2017$ & $2,960,310,153$ & $136,681,523$ & $2,823,628,630$ \\
\hline $2017-2018$ & $3,485,450,033$ & $118,643,326$ & $3,366,806,707$ \\
\hline $2018-2019$ & $3,580,312,392$ & $92,969,950$ & $3,487,342,442$ \\
\hline $2019-2020$ & $4,060,472,271$ & $128,577,275$ & $3,931,894,996$ \\
\hline
\end{tabular}

Source: Secondary Data

The table above shows that the contribution is lowest in the period 2016-2017 and highest in the period 2019-2020. The company's increase steadily as year passes by.

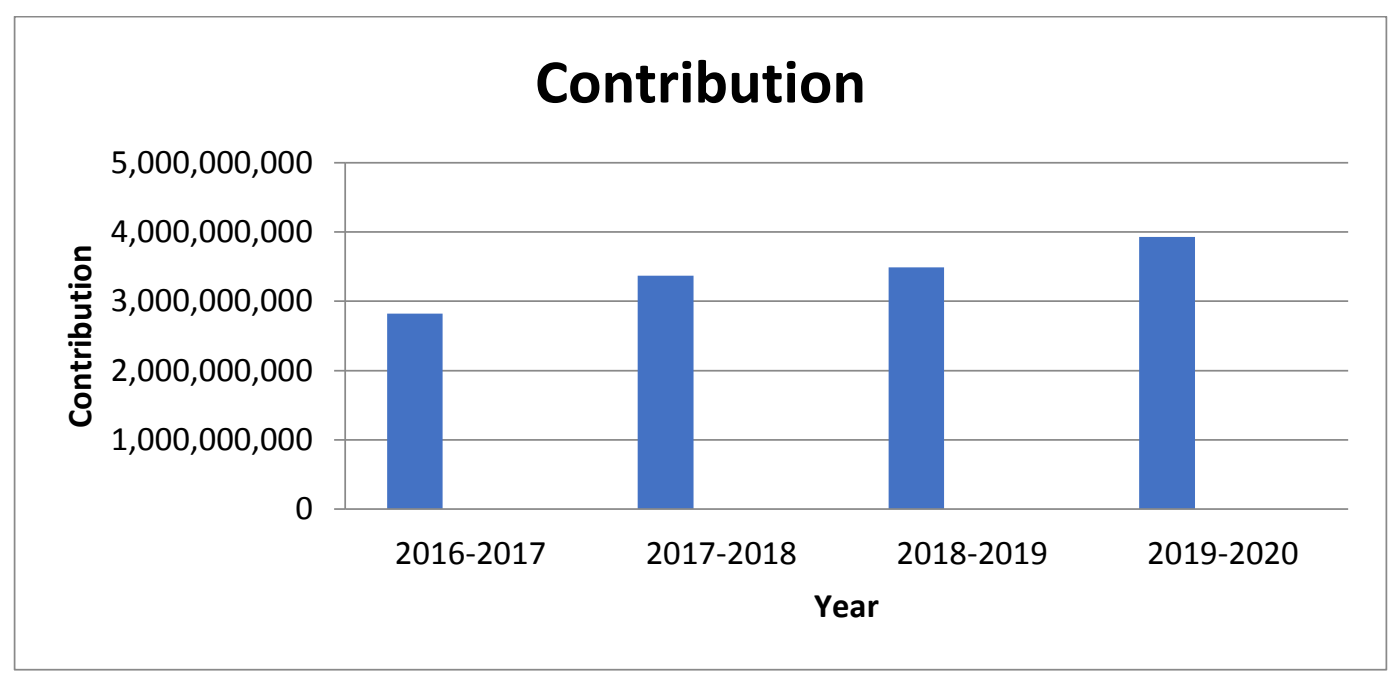

Profit Volume Ratio

Figure 2: Contribution

Profit Volume Ratio is also known as Contribution ratio. It depicts the relationship between contribution and sales.

$\mathbf{P} / \mathrm{V}$ Ratio $=($ Contribution/Sales $) * 100$

Table 2: Profit Volume Ratio

\begin{tabular}{|l|l|l|l|}
\hline Year & Contribution & Sales & P/V Ratio \\
\hline $2016-2017$ & $2,823,628,630$ & $2,960,310,153$ & $95.4 \%$ \\
\hline $2017-2018$ & $3,366,806,707$ & $3,485,450,033$ & $96.6 \%$ \\
\hline $2018-2019$ & $3,487,342,442$ & $3,580,312,392$ & $97.4 \%$ \\
\hline $2019-2020$ & $3,931,894,996$ & $4,060,472,271$ & $96.8 \%$ \\
\hline
\end{tabular}

It can be observed from the above table that the P/V Ratio is gradually increasing throughout the studied periods except for a slight fall in the period 2019-2020. The P/V Ratio was lowest in the period 2016-2017 and highest in the period 2018-2019. 
International Advanced Research Journal in Science, Engineering and Technology

Vol. 8, Issue 11, November 2021

DOI: $10.17148 /$ IARJSET.2021.81108

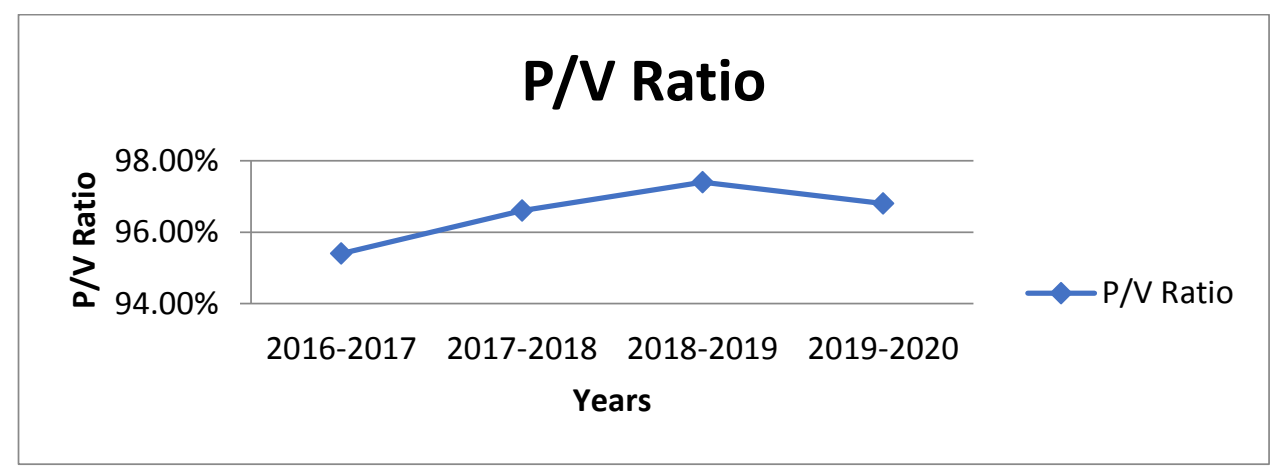

Figure 3: P/V Ratio

\section{Break-Even Point}

Break Even analysis is a method of anticipating the connection between sales income, variable expense and fixed expense to select the degree of operation at the processing plant. The breakeven point is a level where there is no profit and no loss.

\section{Break-Even point= Fixed Cost/ Profit Volume Ratio}

Table 3: Break-Even Point

\begin{tabular}{|l|l|l|l|}
\hline \multicolumn{1}{|c|}{ Year } & Fixed Cost & P/V Ratio & Break-Even Point \\
\hline $2016-2017$ & $268,073,126$ & $95.4 \%$ & $280,999,083.9$ \\
\hline $2017-2018$ & $294,314,354$ & $96.6 \%$ & $304,673,244.3$ \\
\hline $2018-2019$ & $246,586,848$ & $97.4 \%$ & $253,169,248.5$ \\
\hline $2019-2020$ & $192,649,746$ & $96.8 \%$ & $199,018,332.6$ \\
\hline
\end{tabular}

Source: Secondary Data. Fixed cost was calculated by adding all the fixed expenses from the annual report of the plant. Break-Even Point is fluctuating at the studied years. The amount was highest in the year 2017-2018 and lowest in the year 2019-2020.

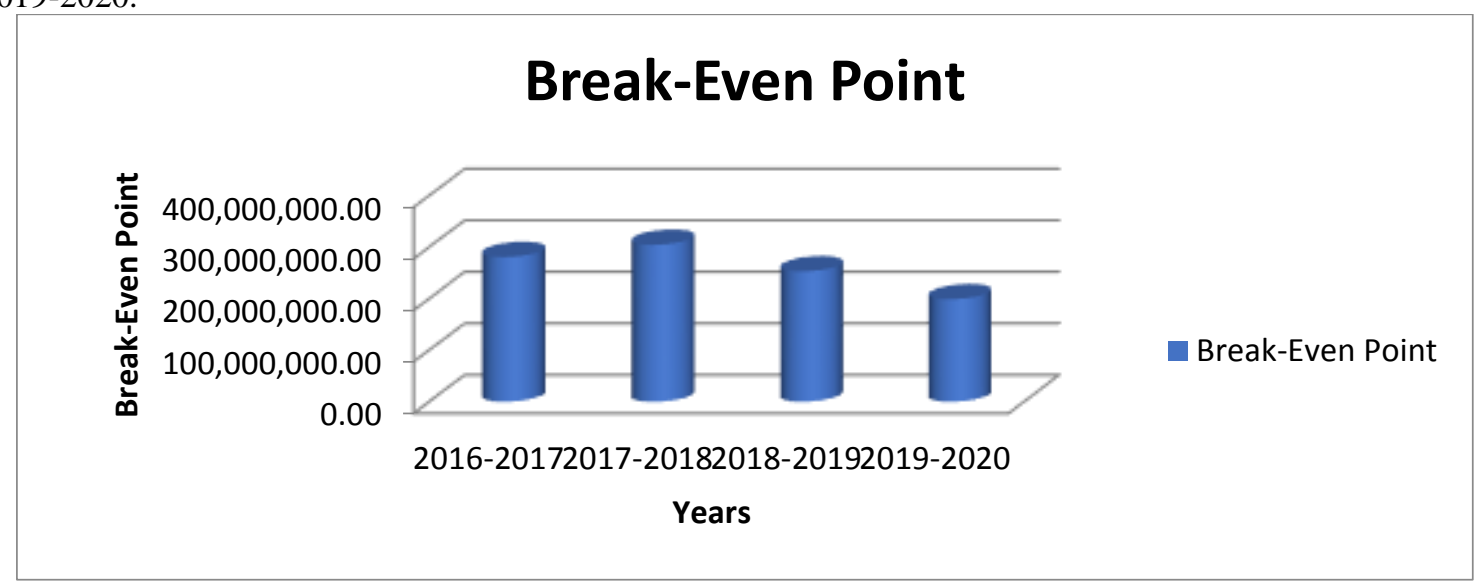

Figure 4: Break-Even Point

\section{Break Even Ratio}

Break Even Ratio is the relationship between break-even sales and sales of a business. The formula for calculating Break Even Ratio is:

Break Even Ratio= $($ Break-Even point/Actual Sales $) * 100$

Table 4: Break-Even Ratio

\begin{tabular}{|l|l|l|l|}
\hline Year & Break-Even Point & Sales (Tk) & Break Even Ratio \\
\hline $2016-2017$ & $280,999,083.9$ & $2,960,310,153$ & $9.5 \%$ \\
\hline $2017-2018$ & $304,673,244.3$ & $3,485,450,033$ & $8.7 \%$ \\
\hline $2018-2019$ & $253,169,248.5$ & $3,580,312,392$ & $7.1 \%$ \\
\hline $2019-2020$ & $199,018,332.6$ & $4,060,472,271$ & $4.9 \%$ \\
\hline
\end{tabular}

The table above shows inconsistent results of Break Even Ratio in the years 2016-2020. The results were highest in the period 2016-2017 and lowest in the period 2019-2020. 
International Advanced Research Journal in Science, Engineering and Technology

Vol. 8, Issue 11, November 2021

DOI: $10.17148 /$ IARJSET.2021.81108

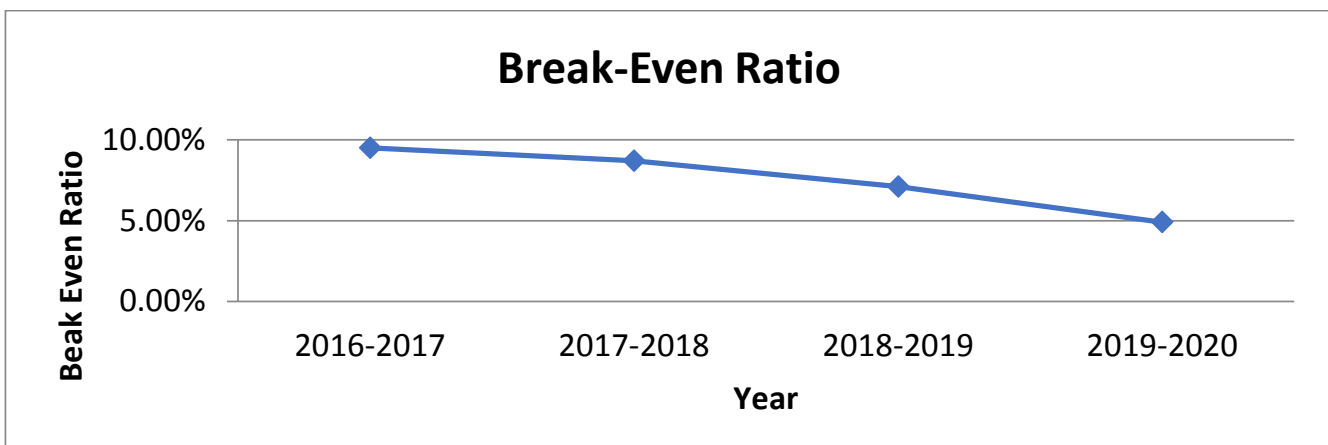

Figure 5: Break Even Ratio

\section{Margin of Safety in Tk}

This refers to the excess of actual sales over the break even volume of sales.

Margin of Safety $($ MOS) $=$ Sales- Break even sales

Table 6: Margin of Safety in Tk

\begin{tabular}{|l|l|l|l|}
\hline Year & Sales (Tk) & Break-Even Sales & MOS in Tk \\
\hline $2016-2017$ & $2,960,310,153$ & $280,999,083.9$ & $2,679,311,069.1$ \\
\hline $2017-2018$ & $3,485,450,033$ & $304,673,244.3$ & $3,180,776,788.7$ \\
\hline $2018-2019$ & $3,580,312,392$ & $253,169,248.5$ & $3,327,143,143.5$ \\
\hline $2019-2020$ & $4,060,472,271$ & $199,018,332.6$ & $3,861,453,938.4$ \\
\hline
\end{tabular}

The table above shows that the amount of margin of safety has been increasing from the year 2016-2020. The amount has been the highest in the period 2019-2020 and lowest in the period 2016-2017.

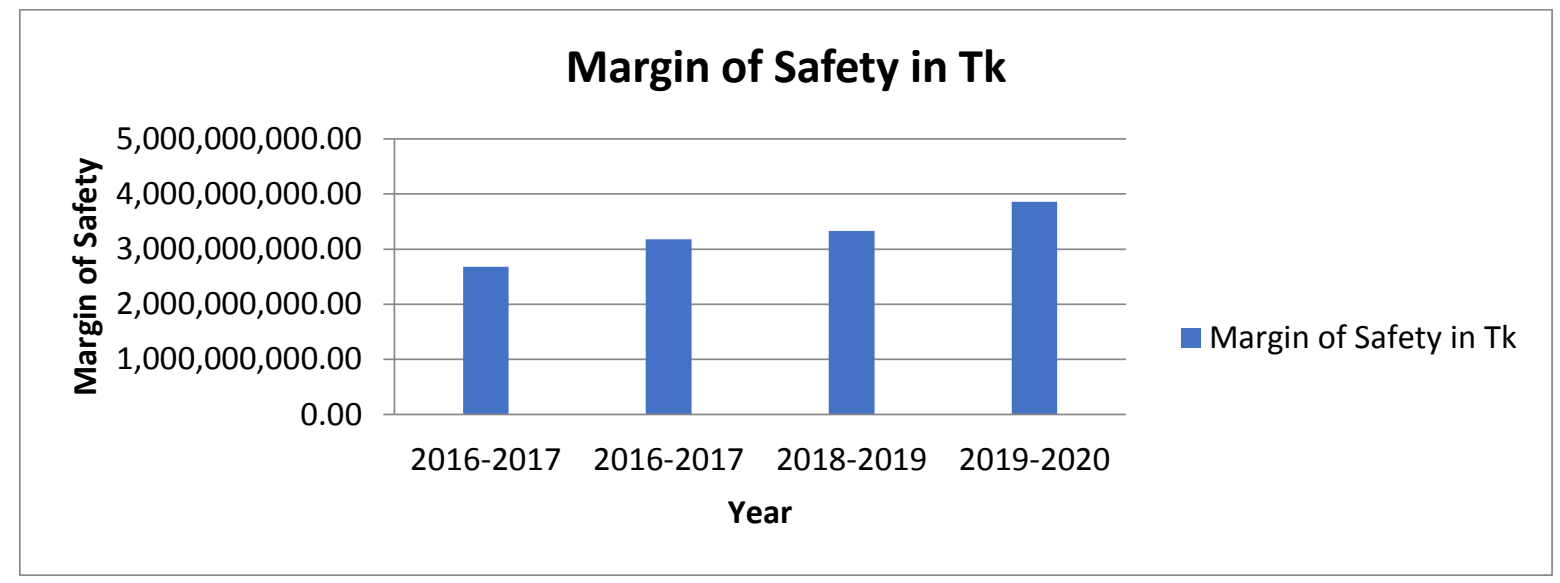

Figure 7: Margin of Safety

\section{B. INTERPRETATION:}

Over the years sales of Baraka Power Limited has increased. The company has seen a dramatic increase in its sales from 2,960,310,153 in the period 2016-2017 to 3,485,450,033 in 2017-2018. It was mainly because the subsidiary companies of Baraka Power Limited has been effectively producing and delivering the required electricity to the national grid of Bangladesh. The plants have been operating well and giving out profitable returns. Alongside, in the same span of time, the company had acquired a Ready-Made Garments industry where the company holds 51\% of the equity of the company. This investment had played a strong role at increasing their P/V Ratio from $95.4 \%$ in the period $2016-2017$ to $96.6 \%$ in 2017-2018. In the period of 2018-2019 sales has increased from 3,485,450,033 in 2017-2018 to 3,580,312,392. The P/V Ratio also increased from $96.6 \%$ in $2017-2018$ to $97.4 \%$ in $2018-2019$. The company made investments at certain projects and equipment which made them earn increasing revenues than the earlier periods. In the period of 2019-2020 the sales has increased from 3,580,312,392 in 2018-2019 to 4,060,472,271 in 2019-2020. This is because of an increase in energy proceeds. However, the P/V Ratio has decreased from $97.4 \%$ in the period of 2018-2019 to $96.8 \%$ in 2019-2020. This is mainly because of a slight rise in cost of goods sold and operational expenses and reduction at other incomes compare to the previous period. 


\title{
International Advanced Research Journal in Science, Engineering and Technology
}

\author{
Vol. 8, Issue 11, November 2021
}

DOI: $10.17148 /$ IARJSET.2021.81108

The Break-Even point shows a fluctuating pattern which shows the instability. It is important to increase the sales and contribution to maintain the stability of Break-Even point. The Break-Even ratio is also fluctuating which means that it is very much important to improve the break-even point.

From the amount of Margin of safety a company can understand the risk of loss to which a business is subjected by changes in sales. Margin of Safety is greater in every year which means the company is less sensitive to any unexpected fall in revenue.

\section{LIMITATIONS:}

The CVP analysis method has been mainly used for measuring the performance of Baraka Power Limited in preparing this report. As the report mainly considered collecting data from the Annual Reports of the company, there are certain limitations as stated below:

1. Types of cost should be precisely categorized as either fixed cost or variable cost but it was very difficult to recognize actual variable and fixed cost from the annual reports of the company.

2. Because of the changes of sales volume, selling prices per unit and variable cost might have changed, even though they should have been constant.

3. Fixed costs should be constant but it has been seen in the reports as changing over a period of time.

4. It was also difficult to find out number of the product.

\section{CONCLUSION \& RECOMMENDTION:}

\section{Conclusion}

It can therefore be summarized by saying that the organization can use cost volume profit analysis to analyze the profitability position of the concerned company. Cost-Volume-Profit analysis has been used to identify the profitability position of the company which was further studied using all available information to conduct the break-even analysis. After studying the various data related to the Baraka Power Limited from the period 2016-2020, it can be said that the sale and contribution of the company were increasing steadily from the period 2016-2020. However, the company has seen fluctuating results of its profit-volume ration and break even sales. This indicates that the company should emphasize on lowering its fixed costs and increasing its sales for boosting its profitability. The company has been having a positive margin of safety throughout the studied period which showed its efficient performance of handling its inventories. The company should use managerial tools such as cost volume profit analysis to identify it's any upcoming risks. CostVolume-Profit analysis can be an enormously valuable device for determining possible success of a business organization.

\section{Recommendation}

1. The company should work on increasing their sales which in turn can increase their contribution.

2. Sales and contribution should also be increased in order to maintain the stability of Break-Even point.

3. By enhancing the Break-Even point there can be seen an upgraded ratio of Break-Even

4. Costs should be more clearly classified for easier calculations of managerial accounting.

5. Company should use CVP analysis to make short-term decisions. It can also help the company to design new programs and implement strategies, and find out possible risks.

\section{REFERENCES}

1. Md. Ziaur Rahman Khan, Saiful Islam, ( 2017), A Review of Energy Sector of Bangladesh, 1st International Conference on Energy and Power, ICEP2016, 14-16 December 2016, RMIT University, Melbourne, Australia DOI:10.1016/j.egypro. 2017.03.193

2. Annual-Report-2019-2020-of-Baraka-Power-Ltd.-1.pdf, ANNUAL REPORT 2019-2020, BARAKA POWER LIMITED

3. Abdullahi, R. S. (2015). Mastering Cost and Management Accounting.(3rd ed) Kano: Sharif Mahir Investment Ltd

4. Adeniyi, A. A. (2008). An Insight into Management Accounting (4th ed.). Lagos, Nigeria: El - Toda Ventures Limited.

5. An Overview of Power Sector of Bangladesh, November, 2011 Bangladesh Power Development Board, https://usea.org/sites/default/files/event-file/493/overviewofbpdb.pdf

6. B. Navaneetha, K. Punitha, Raichu Mercy Joseph, S. Rashmi, T. Sai Aishwariya (2017), "An Analysis of Cost Volume Profit of Nestle Limited", International Journal of Commerce and Management Research, Volume 3, Issue 3.

7. Blocher, E., \& Chen, K. H. (2004), The ALLTEL Pavilion Case: Strategy and CVP Analysis. Issues in Accounting Education, 19(4), 555565. Retrieved 2 23, 2019, from http://aaajournals.org/doi/abs/10.2308/iace.2004.19.4.555

8. Colin, D. (2008). Management and Cost Accounting. . London: .Booking Power Publishers.

9. Collins, D., Chan, L., \& Román, F. J. (2011), An Empirical Investigation of the Relationship Between Profit Margin Persistence and Firms' Choice of Business Model: Evidence from the US Airline Industry. Journal of Management Accounting Research, 23(1), 37-70. Retrieved 2 22, 2019, from http://aaajournals.org/doi/10.2308/jmar-10124

10. Dr Khondaker Golam Moazzem, CPD Mohammad Ali, (2019), The Power and Energy Sector of Bangladesh: Challenges of Moving beyond the Transition Stage, (The paper is presented in a national dialogue on "Power and Energy Sector: Immediate Issues and Challenges" organised by the Centre for Policy Dialogue (CPD) held on 10 March, 2019.) https://cpd.org.bd/wp-content/uploads/2019/03/The-Power-and-Energy-Sector-ofBangladesh.pdf 


\section{International Advanced Research Journal in Science, Engineering and Technology}

\section{Vol. 8, Issue 11, November 2021}

\section{DOI: 10.17148/IARJSET.2021.81108}

11. Dr. R. Kavitha (2018), "Cost Volume Profitability Analysis-An Empirical Study with reference to Salem Steel Authority of India Limited(SAIL)", TamilNadu, International Journal of Business and Management Invention, Volume 7 Issue 5 Ver. II.

12. Dr. Seung Hwan Kim (2015), "Cost Volume Profit Analysis for a Multi-Product Company: Micro Approach", International Journal of Accounting and Financial Reporting, Volume 5, No.1.

13. Energy Sector in Bangladesh: An agenda for reforms" March 2014

14. EnkeledaLulaj, EtemIseni (2018), "Role of CVP as Important Indicator for Planning and Making Decisions in the Business Environment", European Journal of Economics and Business Studies, Volume 4, No 2.

15. Farjana Yeshmin, (2015), A Study on Cost and Management Accounting Mechanism as Practiced in Manufacturing Industry of Bangladesh, Journal of Business Studies, Vol. XXXVI, No. 2, August 2015

16. "Govt plans to sign energy pact with Bangladesh", (2018), The Himalayan Times, 16 April 2018, Retrieved 9 May 2018.

17. Himme, A. (2018), Cost-volume-profit (CVP) analysis. The Business \& Management Collection. Retrieved 2 23, 2019, from https://hstalks.com/t/3708/cost-volume-profit-cvp-analysis.

18. HalilAkmese, Ahmet Buyuksalvarci, Kadriye Akmese (2016), "The Use of Cost Volume Profit Analysis in Turkish Hotel Industry", International Conference Proceedings

19. Jaedicke, R. K., \& Robichek, A. A. (1964), Cost-Volume-Profit-Analysis under Conditions of Uncertainty. Accounting Review, 39(4), 917926.

20. K. Malarkodi ,M. Ranjitha, (2021), An Determinant Analysis of Cost Volume Profit of E.I.D-Parry (India) Limited Pugalur, Annals of R.S.C.B., ISSN:1583-6258, Vol. 25, Issue 5, 2021, Pages. 2315 - 2322 Received 15 April 2021; Accepted 05 May 2021.

21. Mohammad Asrarul Haque,(2020), Bangladesh power sector: An appraisal from a multi-dimensional perspective (Part-1), 03 September 2020, M.Zakir Hossian Khan and M. Rasheduzzman, "Performance of the Power Sector of Bangladesh: Governance Failures and Remedial Measures" , Transparency International Bangladesh (TIB).

22. Magee, R. P. (1975). Cost-Volume-Profit Analysis, Uncertainty and Capital-Market Equilibrium. Journal of Accounting Research, 13(2), 257-266. Retrieved 2 23, 2019, from https://scholars.northwestern.edu/en/publications/cost-volume-profit-analysis-uncertainty-and-capitalmarketequili

23. "Nuclear Power in Bangladesh". world-nuclear.org. Retrieved 8 June 2017.

24. "Present Installed Generation Capacity (MW) as on 30 June, (2018)", bpdb.gov.bd. Bangladesh Power Development Board. Retrieved 17 July 2018.

25. $\quad$ "Present Installed Generation Capacity (MW) as on 30 June, (2018)". bpdb.gov.bd. Bangladesh Power Development Board. Retrieved 17 July 2018.

26. R. Punniyamoorthy (2017), "Examining Cost Volume Profit and Decision Tree Analysis of a Selected Company", World Wide Journal of Multidisciplinary Research and Development, Volume 3, No. 9.

27. Source of Light in Bangladesh : (2015)". Archived from the original on 15 August 2017. Retrieved 8 June 2017.

28. Sadiq Rabiu Abdullahi, Bello Abiodun Sulaimon, Ibrahim Salihu Mukhtar, Muhammed Hardy Musa (2017), "Cost Volume Profit Analysis as a Management Tool for Decision Making in Small Business Enterprise within Bayero University, Kano”, IOSR Journal of Busine ss and Management, Volume 19, Issue 2 Ver I"Key Statistics". Bangladesh Power Development Board. Retrieved 3 November 2014

29. Shah Haider Mali kali and Malik Muhammad Shaukat, (2011). 'Strategic management accounting - a messiah for management accounting?' Australian Journal of Business and Management Research Vol. 1, No. 4 [01-07]

30. Simshauser, P., \& Ariyaratnam, J. (2014), What is normal profit for power generation, Journal of Financial Economic Policy, 6(2), 152178. Retrieved 2 23, 2019, from https://ideas.repec.org/a/eme/jfeppp/v6y2014i2p152-178.html. 